\title{
Role of Indian Post in Financial Inclusion
}

\author{
Dipankar Malakar \\ Research Scholar Gauhati University Assam, India
}

\begin{abstract}
Financial inclusion is assumed to be one of the key drivers of our vision of an inclusive society and inclusive economy. During post liberalization period the banking sector has grown enormously keeping pace with and in some cases leading the country's remarkable economic growth. At the same time Indian post offices are also providing banking services to the all section of people of the society since 1882. Indian post served Indian villagers as banker much before financial inclusion become buzzword and Indian post claims to be the pioneer of financial inclusion in India.

Through this paper an attempt has been made to study the role played by Indian post in financial inclusion and the challenges before the Indian post in providing banking services to the masses.

While preparing the paper data and information's are collected from the department of post, discussion are holds with officials of Indian post and accordingly analysis is made.
\end{abstract}

Key words: Indian post, financial inclusion, post office savings bank account.

\section{Introduction}

During post liberalization period the banking sector in India has grown enormously keeping pace with and in some cases leading the country's remarkable economic growth. The banking system has improved its strength, efficiency and resilience. The branches of commercial banks including RRBs have increased from 8321 in the year 1969 to 93080 in 2011. The average population per bank branch has decreased from 64,000 in 1969 to 13,466 in 2011. Despite such increase in bank branches formal banking system has simply fail to reach to the common masses of the country and all developments are seems to be deficient.

Financial inclusion is not an Indian specific problem, it is global one. The Deputy Governor, Reserve Bank of India, Dr.K.C. Chakrabarty in one of his address at the BIS-BNM Workshop on Financial Inclusion Indicators at Kuala Lumpur on November 5, 2012 said "Across the globe 2.5 billion adults do not use formal financial service to save or borrow. In India, Just about 40 per cent of the population across the country has bank accounts. The proportion of people having any kind of life insurance cover is as low as 10 per cent and proportion having non-life insurance is abysmally low at 0.6 per cent. People having debit cards comprise only 13 per cent and those having credit cards only a marginal 2 per cent of the population".

Other than banking and other financial institution the Indian post which partially do banking activity under the ministry of finance is doing a commendable job towards providing easy financial services to the people throughout the country especially in the remote areas through its huge network.

\section{What is financial exclusion and inclusion}

In simple term financial exclusion means lack of access to formal financial services. It is very transparent that financial services are used only by a section of the population. There is demand for these services but it has not been provided. The excluded regions are rural, poor regions and also those living in harsh climatic conditions where it is difficult to provide these financial services. The excluded population then has to rely on informal sector (moneylenders etc) for availing finance that is usually at exorbitant rates.

Financial inclusion is the availability of banking services at an affordable cost to disadvantaged and low-income groups. In India the basic concept of financial inclusion is having a saving or current account with any bank. In reality it includes loans, insurance services and much more. In advanced economies, Financial Inclusion is more about the knowledge of fair and transparent financial products and a focus on financial literacy. In emerging economies, it is a question of both access to financial products and knowledge about their fairness and transparency.

\section{Objective of the study}

This paper is prepared with the objective of study the role of post office in financial inclusion, challenges before the post office in providing financial services and to provide some suggestions for making Indian post a good conduit for financial inclusion. 


\section{Methodology}

The paper is basically a descriptive one. The paper tries to review, what role the post office is playing in financial inclusion. While preparing the paper both primary and secondary data were collected. Primary data was collected from Office of The Chief Post Master General, Assam Circle, Meghdut Bhavan, Guwahati. Secondary data was collected from annual administrative report, annual report and websites of the Indian post and from publications of RBI. Data collected from both primary and secondary sources are summarized and conclusions are drawn and depending upon the conclusion some suggestions are made.

\section{Indian Post an overview}

The first post office in India was established by East India Company in the year 1688 in Bombay followed by Calcutta and Madras. It was named as 'Company Mail'. The Post Office Department of the East India Company was first established on March 31, 1774 at Calcutta, followed in 1778 at Madras and in 1792 at Bombay. The present type of post office came in to being in the year 1854 under the post office Act of 1854 . The Indian post office has a huge network of branches with an unique outreach in rural areas. In the year 1861 total number of post offices in India were 889. The number of post offices in India increase from 23,344 in 1947 to $1,54,866$ as on 31-03-2011. Out of total post offices in India 1,39,040 numbers post offices are in rural areas which accounts for $89.78 \%$ of India's total post office and remaining 15,826 numbers of post offices situated in urban areas which is only $10.22 \%$ of total numbers of post offices. Apart from providing regular postal service's the post offices in India are also providing financial services to the public through Post Office Savings Bank. The Indian Post starts Postal Life Insurance in the year 1984 as a welfare scheme for the employees of the Post and Telegram Department due to huge demand of the scheme latter on it was opened for employees of other departments and finally in the year 1995 it was opened for all people. In addition to these services post office also provide money transfer services. Post Office Savings Bank which was establish with an objective of encouraging saving habit and thrift among the masses has now become a medium of mobilizing a huge amount of funds.

\section{Post office, commercial banks and financial inclusion in India a critical look}

Despite taking various initiative from the part of government, RBI and commercial banks the banking sector in India has so far not been able to provide complete coverage in the country especially in the rural areas. There are 171 commercial banks in the country. Out of the 93,080 Commercial Banks' branches only $36.10 \%$ are in rural areas and $24.76 \%$ in semi-urban areas. All India average population served by per branch is 13,503 . On the other hand, out of 1.55 lakhs Post offices, $89.8 \%$ i.e. 1.39 lakhs are in rural areas covering an population of 5,682 per Post office in rural areas and 20,346 in urban areas, on an average 7,176 people are served by one post office as on March 2011. On an average, a post office serves an area of 21.23 sq. k.m. Further, only $5 \%$ of 6 lakhs villages have bank branches. Two hundred ninety six (296) districts in states are underbanked, i.e. they have below-par banking services.

The Indian post office offering a plethora of financial services throughout its all branches. This includes various post office savings schemes, postal life insurance, mutual fund, money remittance, forex services etc. As on March 31, 2011, there are nearly 25 crore postal savings bank account under various post office savings bank schemes. The Department of Posts has taken the responsibility to disburse the MGNREGA wages through Post Offices by opening savings bank accounts in the names of MGNREGA beneficiaries. Starting with Andhra Pradesh Postal Circle in 2005, the Scheme of disbursement of MGNREGA wages through Post Offices accounts is currently operational in the entire country excepting Delhi, Jammu \& Kashmir and Tamil Nadu Postal Circles (Tamil Nadu and Puducherry). The Department is also contributing to the efforts in financial inclusion by payment of benefits under various social security pension schemes viz. IGNOAPS (Indira Gandhi National Old Age Pension Scheme), IGNWPS (Indira Gandhi National Disability Pension Scheme) and Indira Gandhi Matritva Sahyog Yojana (IGMSY Scheme), a Conditional Cash Transfer (CCT) Maternity Benefit Scheme. Such payments are being effected either through money orders or Post Office Saving Bank accounts.

The Government's financial inclusion plan aims to provide banking services to 73,000 villages each having a population of 2000. This could be effectively and adequately provided by the PBI operating through postal network and thereby help to spread the savings habit. In this regard setting up of a Postal Bank will assist the Government in its plan for financial inclusion besides mobilizing deposits, especially in the under- served rural and semi-urban areas of the country.

\section{Different saving product of Indian post office}

a) Saving account scheme: Post office saving bank account (POSB) is the oldest and most popular postal saving instrument. Any individual can open a POSB A/C with a minimum balance of Rs-50/. A pass book is 
provided to the $\mathrm{A} / \mathrm{C}$ holder and Cheque facility is also available for POSB A/C. Currently the rate of interest offered against POSB A/C is 4\%. This Account is regulated by The Government Savings Bank Act of 1873.

b) Recurring deposit scheme: Post office offers recurring deposit facility with a maturity period of five years. The minimum deposit is Rs 10/ and multiples of Rs 5/ thereafter and there is no limit of maximum deposit. The present rate of interest offered against this $\mathrm{A} / \mathrm{C}$ is $8.4 \%$. Premature closer is allowed after three year and part withdrawal is also allowed. Four defaults are allowed, more than four default lead to closer of the account. Depositors are provided with one passbook.

c) Time deposit account: Post office offers time deposit for one year, two year, three year and five year. The rate of interest allowed is $8.2 \%, 8.3 \%, 8.4 \%$, and $8.5 \%$ for one year, two year, three year and five years term deposit respectively. The minimum amount required to deposit is Rs 200/ with no maximum limit. Premature withdrawal is allowed after expiry of six month.

d) Monthly Income Scheme: under this scheme the severs make a lump-sum deposit, which gives him a monthly interest. The minimum deposit in case of single depositor is Rs 1000/ and in case of joint depositor it is Rs 1500/. Maturity period is five years and rate of interest allowed is $8.5 \%$. Depositors are provided with one passbook.

e) National Savings Certificate: This is a tax exempted certificate sold by post office with a minimum investment of Rs 100/ and having no maximum limit. Certificates are available in the denomination of Rs 100/, $500 /, 1000 /, 5000 /$ and 10,000. Rate of interest is allowed at 8.9\%. Trust and HUF are not allowed to invest in NSC.

f) Public provident fund scheme: This is a tax advantage 15 years scheme with a minimum deposit of Rs 500/ in a financial year and a maximum of Rs 70,000/ per year. Withdrawal is allowed after expiry of five years from the date of initial deposit. Interest is allowed at $8.8 \%$ per annum. Depositors are provided with one passbook.

g) Postal Life Insurance: besides above mention saving schemes the Indian post offering life insurance services since 1884. Initially the service was limited only to the employee of post \& telegram department but due to its popularity the service was later on extended to the employees of some other departments and banks also. It was opened for all people in the year 1995.

h) Rural Postal Life Insurance: To extend the life insurance service to the rural public the post office extended the service to rural areas in 1995. The prime objective of the scheme is to provide insurance cover to the rural public in general and to benefit weaker sections and women workers of rural areas in particular and also to spread insurance awareness among the rural population.

\section{Problems and challenges}

There is no doubt of the fact that Indian post is playing a very important role in financial inclusion but it can play a much better role if it can overcome from the following problems:

a) Lack of basic infrastructure: The post offices in India, especially post offices in rural areas which playing an important role in providing financial services in rural areas are not equipped with basic infrastructure. In most of the post offices even proper sitting arrangement for staff is not available.

b) Less numbers of staff: There is a crunch of manpower in the post offices. It is observed that most of the post offices are run by one or two persons and need to do all sorts of work which has a very adverse effect on performance and output.

c) Lack of coordination: There are many examples in the foreign countries where post offices are doing tremendous work for financial inclusion in coordination with other departments. But, till today Indian post keep itself away from other sister organization or other organization also not seeking coordination of Indian post in providing financial services.

d) Slow progress of innovation: To cope with the fast changing environment Indian post also need to be catching the new invention and technology timely. The Indian post still following the age old practices of working, though it bringing some innovation recently but in a very slow speed. Out of total post offices only 25464 post offices are computerized till 2011-12. 
e) Abstain from landing: Providing loan is one of the major aspects of financial inclusion but Indian post is not till today taking it as a part of its business which has narrowed down its operation.

Despite having these problems it has some other difficulties too in expanding its area of operation. From the verbal discussion with the officials it is observed that being a government department they cannot take a decision independently.

\section{Way forward}

The expert committee on Harnessing the India Post Network for Financial Inclusion is of the opinion that "succeeding with universal access to financial services will require a considerable role for post offices. In parallel, and as some traditional functions of the postal network are being supplanted by new technologies such as email, India Post is also in the process of carving out a larger role for itself. Therefore, there is a remarkable coincidence of needs between the twin problems of (a) charting the future for India Post, and (b) resolving India's challenges of financial inclusion".

In terms of number of branches and customer the Post Office Savings Bank is all ready the largest bank in the country. There is no doubt of the fact that the Indian Post can lead the way in financial inclusion with its given network and reach. It can increase its importance and profit provided it can bring together all the stakeholders in to a single platform, bring the necessary reforms, adopt the innovation and take some policy appropriate with the situation. The Indian post has all ready adopt certain reform measures for innovation and technological upgradation. Government had approved IT modernization project for computerization of all the non computerized post offices, establishment of required IT infrastructure and development of software. A pilot project on core banking solution and Information and Communication Technology (ICT) is going on in six circle. The project is supposed to be completed by 2014. Indian post also take decision to establish 1000 ATMs throughout the country.

I strongly believe if Indian post can make coordination with other stakeholders, infuse necessary human resource with proper training and technology, bring innovation and other appropriate measures the Indian post can reap the benefits of its huge network, extensive outreach and lower cost and at the same time it will able to contribute towards the national objective of financial inclusion. Establishment of Post Bank of India may be another strong decision to associate Indian post in financial inclusion. Indian post has already applied to the RBI for a banking license; if the license is given it will be a great achievement for Indian post which will enable post offices to perform full banking activities. Indian post can give a new dimension to the process of financial inclusion and can reach an extra mileage in the field of financial inclusion. Indian post can start the journey where Indian banking system stops.

\section{References:}

[1] A Profile of Banks,2010-11,RBI

[2] Annual Administrative Report, 2010-2011, Assam Postal Circle

[3] Annual Report, 2010-2011, Indian Post

[4] Branch Banking Statistics, RBI, 2009

[5] Chakrabarty K.C., Deputy Governor, Reserve Bank of India, keynote address at BIS- BNM Workshop on Financial Inclusion Indicators at Kuala Lumpur on November 5, 2012

[6] HM Treasury, 2004, Promoting Financial Inclusion, London, available at www.hm- treasury.gov.uk.

[7] Report of the Committee on Financial Inclusion, 2008, Government of India.

[8] Report of the expert committee on Harnessing the India Post Network for Financial Inclusion, 2010, New Delhi. 